\begin{tabular}{|c|c|c|c|c|c|c|c|c|}
\hline & & & 第 & 4 & 表 & & & \\
\hline \multirow{2}{*}{ 番 号 } & \multirow{2}{*}{$\mathrm{pH}$} & \multirow{2}{*}{$\begin{array}{c}\mathrm{H}_{2} \mathrm{~S} の \text { 濃度 } \\
(\text { vol } \%)\end{array}$} & \multirow{2}{*}{$\begin{array}{c}\mathrm{Fe}(\mathrm{OH})_{3} \\
\left(10^{-4} \text { mole }\right)\end{array}$} & \multirow{2}{*}{$\begin{array}{c}\mathrm{H}_{2} \mathrm{SO}_{4} \\
\left(10^{-4} \text { mole }\right)\end{array}$} & \multicolumn{3}{|c|}{$\mathrm{H}_{2} \mathrm{~S}$ 吸収量 $\left(10^{-4}\right.$ mole $)$} & \multirow{2}{*}{$\begin{array}{c}\text { 還元された } \\
\mathrm{Fe}(\mathrm{OH})_{3} \\
\left(10^{-4} \text { mole }\right)\end{array}$} \\
\hline & & & & & 全吸収量 & 溶 存 & 反 & \\
\hline 17 & 7.6 & 0.60 & 5 & - & 9.79 & 1.55 & 8.24 & - \\
\hline 18 & 4.5 & 0.49 & 5 & 微量 & 7.55 & 1.28 & 6.27 & 1.23 \\
\hline 19 & 3.4 & 0.62 & 5 & 1.61 & 7.08 & 1.62 & 5.46 & 2.04 \\
\hline 20 & 3.0 & 0.57 & 5 & 2.87 & 4.09 & 1.45 & 3.64 & 3.86 \\
\hline 21 & 3.4 & 0.45 & 5 & 1.61 & 6.12 & 1.18 & 4.94 & 2.56 \\
\hline 22 & 3.4 & 0.44 & 3 & $1: 61$ & 3.24 & 1.15 & 2.09 & 2.41 \\
\hline
\end{tabular}

の厥係より算山乚したもので亦る。このように最初の水酸 化第二鉄の星が同じ㭙流初の $\mathrm{pH}$ ぶ低い活ど硫化水素 の吸收量は少なく，また最初の $\mathrm{pH}$ が同じ时は水酸化第 二鉄の最初の量には無阙係に汪ぼ间星の水陵化第二鉄方; 還元さ机ていることがわかる。

終りにのぞみ，總えず指導と激励㤂たまわった策崎平 照教投打よで終始熟心に実験に協力された没辽潔氏に
心より謝意をささげ実験の一部に協力された小松正明， 梅津幸郎の両氏に感謝する。本研究の一部は文部省科学 研究費によった。

（昭和 30 年 4 月，日本化学会第 8 年会，昭和 30 年 10 月, 日本化学会関東東北支部連合大会, 昭和 31 年 4 月, 日本化学会第 9 年会講演）

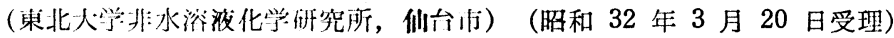

\title{
液安一カセイアルカリによる有譏合成化学（第 $\mathbf{3}$ 報） 液安-カセイアルカリによるグリシン誘導体の $\mathbf{N}-$ ベンジル化
}

\author{
㳀思柳三・下光太郎*・多田律 郎
}

無水グリシン, 策尿酸,フタリルグリシンのメタル置換を液安中の水酸化アルカリによって行い, 引きつづき嫶化ベンジルとの忍によって $\mathrm{N}$ ーベンジル化を武みた。

照㽷酸アミドより $\mathrm{N}$-ベンジル馹尿酸アミドを得たが，フタリルグリシンアミドのばあいにはメ タル置換にさいし開環し，さらに脱フタリルを起すため，ベンジル化の結果， N-ベンジルフタルイ ミドと $\mathrm{N}, \mathrm{N}^{\prime}$-ジベンジルタルイミドを得た。この両者では液安一水酸化アルカリと液安ーアルカ リアミドとを使用するベンジル化の絬果が同じであった。

無水グリシンでは液安一水酸化アルカリによるベンジル化が原料回収とモノベンジルアミンの生 成に終った。これはアルカリ置換体が液安に不溶性なためであり，水酸化アルカリが液安中ではア ルカリアミドと平衡状態にある，とする著者らの考えを支持する。

活州:メチレン化令物の水陵化アルカリによるメタル䠗 換が液安中で可能であることを見だして，マロン酸ジア ミド，シアン酶酸アミドのアルキル化を前報12)で報告 しそのさいに液安一水酸化アルカリによるメタル置換の 特異性を論じた。著者らの考えにしたがえばこの液㚣一

1）前報 (第 2 報) 工化 60, 1036 (1957).

* 現在防衛大学校化学教室, 横須賀市.

2）浅見，下，工化 60, 1034 (1957).
水酸化アルカリは従来の液安一水酸化アルカリアミドに 匹敵する効果を持っており，かならずしも活性メチレン のメタル置換のみならず，ほかの反応にも利用し得る。 一例として活性メチレン以外の活性水素のメタル置換も 可能であることが推定される。このような活性水素を有 する化合物としてはア之ノ基 $\left(-\mathrm{NH}_{2}\right)$, 水酸基 $(-\mathrm{OH})$ を持つ化合物があげられる。一力これら化合物の液安一 金属アルカリ,液安ーアルカリアミドによるメタル置換お 
よびハロゲンアルキルとの反応でアルキル化を行う例は すでに発表されているぶ。著者らもグリシシ誘導体の Nメタル置換および八ロゲンアルキルによるアルキル化在 試みこれに関する二，三の知見をすでに報告した4)。 グリシン誘導体として無水グリシン（ジケトピペラジ ン), 馬尿酸, フタリルグリシンのばあいそれぞれ特徴あ る反応過程をたどることを示した。ここではこれら試料 の液安一水酸化アルカリによるメタル置換と,䘏化ベンジ ルによるベンジル化を金属アルカリ，アルカリアミドに よる場合と比較するために行った。

1. 無水グリシン: 無水グリシン $(\mathrm{G} \mathrm{A})$ は液安中ア ルカリアミドおよび金属アルカリアミドによってメタル 置換を受けそのまま液安中，塩化ベンジルとの反応にお いてベンジルアミンを生成することなく, N, $\mathrm{N}^{\prime}$-ジベン ジル無水グリシン（I）を与える。

一なわち $\mathrm{N}$-ベンジル化の順調な例である4)。<smiles>NNC(=O)[C@H](NC(=O)[C@@H](N)C(=O)O)C(=O)N[C@@H](N)C(=O)O</smiles>
( I)

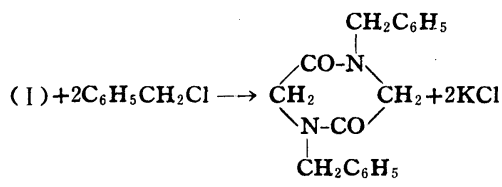

(I)

ここでは G Aの液安中での水酸化アルカリによるメタ ル置換を試みた。前報122) までのこの方法では水酸化ア ルカリは液安不溶性であるが，アルカリ置換体が液安に 可溶性となるためにガラス製耐圧反応管を使用し，水酸 化アルカリの消失によってメタル置換の終結を観察する ことができた。しかるにGAのアルカリ置換体（Ｉ）は液 安不溶性であるため, 同じく不溶性である水酸化アルカ リによるメタル置換注従来にくらべて不利と思われ，事 実 GA と水酸化ナトリウムとを液安中に長時間放置した のであるが, 不溶性水酸化ナトリりムの消失㭠られず， 外観状の変化もほとんど認められなかった。つぎにこの 状態で当量以上の塭化ベンジルを加えてベンジル化を試 みたのであるが，その結果は GAを回収し，モノベンジ ルアミンを分離した。このアミンは塩化ベンジルが水酸 化アルカリによってアミノ化を促進されて生成したもの であり，とくにこのばあいにモノアミンが大部分である ことは，液安一水酸化アルカリを利用する第 1 級アミノ 生成反応に暗示を与え, 水酸化アルカリによるハロゲン

3）下, 多田, 東北大学非水研報告 4, 149 (1954); 下, 安藤, 布施, 同誌 4, 143 (1954).

4) 下, 减見, 同誌 4, 69, 75 (1954)
アルキルのアミノ化については別報で報告する。以上の 結果よりして GAでは置換が進んだとしても不溶性粒 状水酸化アルカリの表面のみに限ら机，ベンジル化も

$$
\mathrm{C}_{6} \mathrm{H}_{5} \mathrm{CH}_{2} \mathrm{Cl}+\mathrm{NH}_{3}+\mathrm{NaOH}
$$

$$
\longrightarrow \mathrm{C}_{6} \mathrm{H}_{5} \mathrm{CH}_{2} \mathrm{NH}_{2}+\mathrm{NaCl}+\mathrm{H}_{2} \mathrm{O}
$$

塩化ベンジルのアミノ化が優先的に進行して, $\mathrm{N}, \mathrm{N}^{\prime}-シ ゙$ ベンジル無水グリシンは生成しないと思われる。すなわ ち G A はそのアルカリ置換体の難溶性のために, 液安一 水酸化アルカリと液安-金属アルカリとの反応が 異なる ばあいである。

2. 馬尿酸：液安一金属アルカリを利用する馬尿酸誘 導体のベンジル化の結果としては著者らの報告があ る5)。それによると馬尿酸アミドは液安中金属アルカリ また法アルカリアミドにより液安可溶性のアルカリ置換 体を生じ，そのまま液安中で掹化ベンジルを反応させる と少量ではあるが, $\mathrm{N}$-ベンジル馬尿酸アミド（IN）在得 る。このように低収率であるが $\mathrm{N}$ のできるのは N-メタ ル置換反応の起っていることを示す。

$\mathrm{C}_{6} \mathrm{H}_{5} \mathrm{CONHCH}_{2} \mathrm{CONH}_{2}+\mathrm{Na} / \mathrm{NH}_{3}$

$\rightarrow \mathrm{C}_{6} \mathrm{H}_{5} \mathrm{CO}-\mathrm{N}-\mathrm{CH}_{2} \mathrm{CONH}_{2}+1 / 2 \mathrm{H}_{2}$ $\mathrm{Na}$

(I)

(I) $+\mathrm{C}_{6} \mathrm{H}_{5} \mathrm{CH}_{2} \mathrm{Cl}$

$\longrightarrow \mathrm{C}_{6} \mathrm{H}_{5} \mathrm{CO}-\mathrm{N}-\mathrm{CH}_{2} \mathrm{CONH}_{2}+\mathrm{NaCl}$ $\stackrel{\mathrm{C}}{\mathrm{C}} \mathrm{H}_{2} \mathrm{C}_{6} \mathrm{H}_{5}$

(I)

ここでは原料として馬尿酸エチルエステル (HE), 馬 尿酸アミド（HA），馬尿酸ニトリル（HN）を使用し， 金属アルカリのかわりに水酸化アルカリを使用してメタ ル置換を行った。このばあいのメタル置換体が液安可溶 性であるためにGA とは異なって順調にメタル置換が行 われ，いずれのばあいも 4 〜 時間で不溶性の水酸化ア ルカリは可溶性のアルカリ置換体となって消失すること を観察した。したがってこの液安溶液に塩化ベンジルを 作用させて, N-ベンジル化を行ったが，その結果は試料 の種類により幾分相違を生じた。

HEおよびH Aでは金属アルカリのばあい同様に IV それぞれ 12\%，8\%の収率で得た。そのほかは原料 H A （HEは加アンモニア分解で H A になる）を回収した。 しかし H Nでは生成物は原料 HNで IN は得られなかっ た。

以上のように H N 以外では液安-金属アルカリを用い たばあいと液安一水酸化アルカリのばあいとが同じ 形式 で反応が進行する。H Nではメタル置換の容易に進行す ることはわかるが，ベンジル化にさいしふたたびH Nに

5）下，村上，東北大非水研報告，投稿中. 
もどるようである。
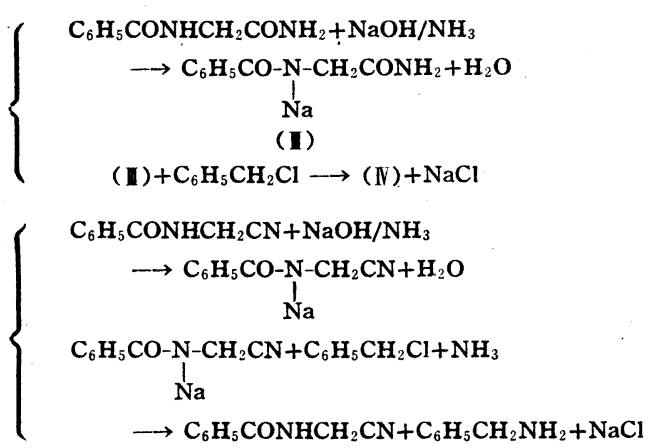

一般にアルカリ置換体と八ロゲンアルキルとの反芯は $S_{\mathrm{N}}$ 形式によってアルキル化が行われるのであるが，馬 尿酸のばあいのように大部分がもとの化合物にもどる反 応は $S_{\mathrm{E}}$ 形式によって反応が進行するためであると説明 できる4)。

3. フタリルグリシン：フタリルグリシンアミド（P $\mathrm{GA})$ ，フタリルグリシンエチルエステル $(\mathrm{P} \mathrm{GE})$, フタ リルグリシンの遊離酸㧍よびそのアルカリ塩はすべて液 安中金属アルカリおよびアルカリアミドによってメタル 置換を受けて可溶性のメタル置換体を生ずるが，これに 液安中で塩化ベンジルを作用させると, ベンジル化の結 果として，N-ベンジルフタルイミド（II）と N, N'-シ ベンジルフタルアミド $(\mathbb{X})$ の混合物觉得る6)。このこ こはフタリルグリシン類ではメタル置換にさいし，開環 置換を行い, ベンジル化によって脱フタリル反応の起る ことを示している。この反応にたいし著者らはつぎのご とく考えている。

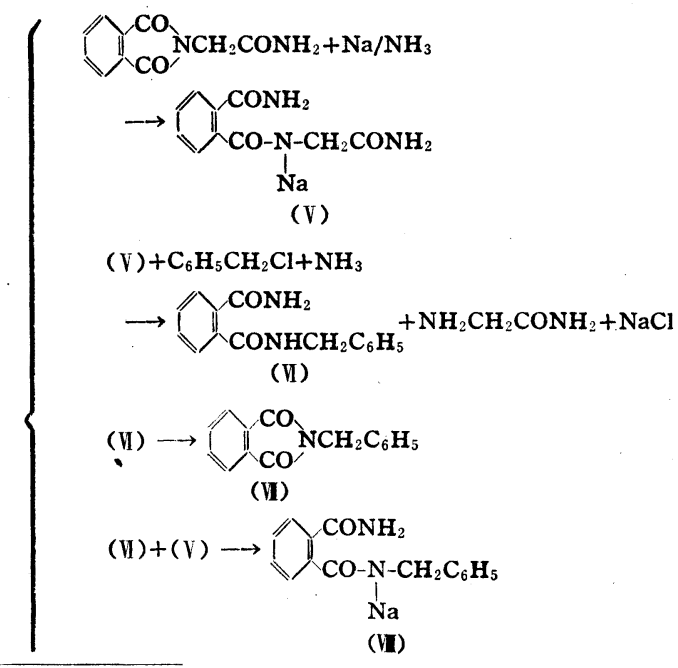

6) 下, 浅見, 日化第 6 年会覆演 (1953).

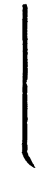

$+\mathrm{MCONHCH}_{2} \mathrm{C}_{6} \mathrm{H}_{5}$

(VI) $+\mathrm{C}_{6} \mathrm{H}_{5} \mathrm{CH}_{2} \mathrm{Cl} \longrightarrow \mathrm{CONHCH}_{2} \mathrm{C}_{6} \mathrm{H}_{5}$

(IX)

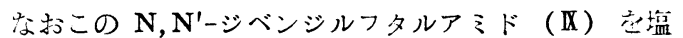

酸と加熱与ると閉環して, N-ベンジルフタルイミド(UI)

こベンジルアミンになること見だした。

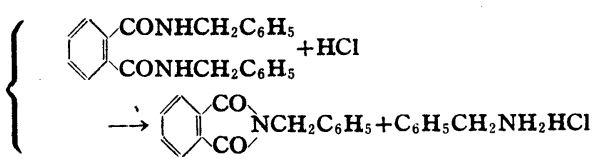

问様の反応を液安中で水酸化アルカリを使用して行っ た。PGA，PGE，PGNをそれでれ液安中で粒状水 酸化アルカリと放置すると 2 ～時間でメタル置換が終 り，透明な液安溶液となる。これに塩化ベンジルを加㫕 てベンジル化を行った。このばあいにも主生成物は䁌之 【であり，ほかにグリシンを確認した。すなおち液安一 水酸化アルカリにおいても金属アルカリ，アルカリアミ ドにおけると同様にフタリルグリシンはメタル置換と同 時に開環し，ベンジル化によって脱フタリルを起してい ることがわかる。一般には切れ難いと考えられているフ タリル基が液安中では水酸化アルカリによってたや方く 開環することは興味深い。

以上 3 種類のグリシン誘導体の 液安一水酸化アルカリ によるメタル置換およびベンジル化をのべたが, その結 果江 G A以外の 2 者では液安一水酸化アルカリアミドに よる反応と全く一致し, 水酸化アルカリが液安中でアル カリアミドと平衡状態にありこのアルカリアミドによ ってメタル置換が進行するものと推定する。

$$
\begin{aligned}
& \left.\mathrm{NaOH} \text { (in } \mathrm{NH}_{3}\right)+\mathrm{NH}_{3} \\
& \rightleftarrows \mathrm{NaNH}_{2}+\mathrm{H}_{2} \mathrm{O} \text { (in } \mathrm{NH}_{3} \text { ) }
\end{aligned}
$$

G Aが様相を異にするのはそのアルカリ置換体が不溶 性であることに帰因し，不溶性水酸化アルカリによメ々 ル置換が水酸化アルカリの表面にの み起り, 塭化ベンジルとの反応も G Aのベンジル化に優先して，塩化 ベンジルのアミノ化が進行するから である。

\section{実 験 の 部}

液安中の反応を常温で行うため第 1 図に示したようなガラス製耐圧容 器を使用した。くわしい使用法は既 報つでのべたとおりである。

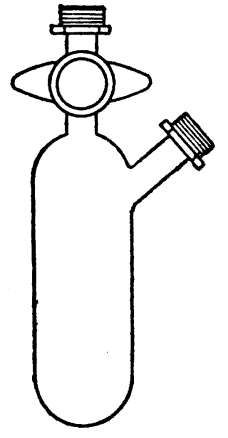

第 1 圀 


\section{1. 試 料}

GAはグリシンエチルエステル塭酸塩より Fischer ( こたぶって合成した白色板状結晶で $250^{\circ} \mathrm{C}$ 以上で分解 する。HE注グリシン夌ベンゾイル化して得た馬尿酸を 常法汇丈ったニステル化した。 $\mathrm{mp} 65^{\circ} \mathrm{C}$ の針状結晶で ある。H A はHEを加アンモニア分解によって酸アミド 化した得た。 $\mathrm{mp} 184^{\circ} \sim 185^{\circ} \mathrm{C}$ の針状結晶である。 $\mathrm{H} \mathrm{N}$ はアミノアセトニトリルの硫酸塩のベンゾィル化で合成 こため。 mp $140^{\circ} \sim 142^{\circ} \mathrm{C}$ の板状結晶である。

P GE，PGAはグリシンと無水フタル酸との溶融だ 得たフタリルジリシン常法によってエステル化し，ま たはアミド化して得た。ともに針状結晶だ，をれだれ $\mathrm{mp} 112^{\circ} \sim 113^{\circ} \mathrm{C}, 254^{\circ} \sim 255^{\circ} \mathrm{C}$ である。 P G N 唖水 フタル酸之メチンンアミノアセトニトリルを縮合して得 だ9。 $\mathrm{mp} 123^{\circ} \sim 124^{\circ} \mathrm{C}$ の葉片状結晶である。

水酸化アル力リ注水酸化ナトリウム之水酸化力リウム 二注市販品粒状物を之のまま使用し，水酸化りチりム注 含水市販品を壱空乾燥した粉末である。それだれ純度は $93,85,98 \%$ ごある。

塩化ベンジルは市販品を炭酸カリウムで脱水し, 脱塩 酸して使用し, 液安注市販品ボンベ入りを数回再蒸留し て使用した。

\section{2. 無水グリシンのメタル置換と塩化ベンジルとの反} 応

G A $1.1 \mathrm{~g}(0.01 \mathrm{~mole})$ と水酸化ナトリウム $0.9 \mathrm{~g}$ $(0.02 \mathrm{~mole})$ 在耐圧管に取り室温で液安 $80 \mathrm{cc}$ を加え る上，GAの溶解する。室温で一夜放置したが水酸化 ナトリウム法そのまま残っている。これに液安の沸点以 下デ程化ベンジル $3 \mathrm{~g}(0.02 \mathrm{~mole})$ を加え, 室温にもど こテふりまぜると，約 4 時間で水酸化ナトリウムは消失 一る。アンモニア充登発して除くと油状を含先結晶を得 る。エーテルミ油状物質を抽出し，不溶物は熱水より再 結晶を行い, $\mathrm{mp} 260^{\circ} \mathrm{C}$ 以上でかつ分解与る板状結晶 $0.7 \mathrm{~g}$ を得たっこのきのを無水酶酸でアセチル化し，ジ アセチル無水3゙リシンとして確認した。 $\mathrm{mp} 100^{\circ} \sim 102^{\circ}$ Cである。エーテル抽出液よりエーテル除去後 $\mathrm{bp}_{3} 48^{\circ}$ $\sim 49^{\circ} \mathrm{C}, n_{\mathrm{D}}^{19} 1.547$ の液体 $2 \mathrm{~g}$ 少得た。このものを塩 酸塩となン，バンジルアミンであることを確認した。こ のベンジルアミン塩酸䘏の $\mathrm{mp} 255^{\circ} \sim 260^{\circ} \mathrm{C}$ 。

水酸化ナトリりム以外に水酸化カリウム，水酸化りチ らム，酢酸さトリりムによりメタル置換を試みたが、い方

7) E. Fischer, Ber. 39, 2903 (1906),

8) K. Haack, Ber. 36, 1646 (1903).

9) H. Stephen, J. Chem. Soc. 1931, 872.
れも原料を回収したのみである。

\section{3. 馬尿酸エステル，アミド，ニトリルのメタル置換} と $\mathrm{N}$-ベンジル化

$\mathrm{HE} \quad 6.0 \mathrm{~g}(0.03 \mathrm{~mole})$, 水酸化ナトリウム $1.3 \mathrm{~g}(0.03$ mole）に液安 $60 \mathrm{cc}$ を加え室温で 4 時間ふりまぜると 粒状水酸化ナトリウムは大部分溶解する。このさいにフ ェノールフタレインを微量添加すると液安溶液は赤色を 呈する。塩化ベンジル $4.2 \mathrm{~g}(0.03 \mathrm{~mole})$ を加え, ふたた びふりまぜると 2 時間で赤色は消えベンジル化は終る。 アンモニア蒸発後の残留物にアルコールを加えて無機塭 を除き，アルコール 溶液からはアルコール蒸発残留物 のクロロホルム抽出を行ってクロロホルム不溶性の結晶 (A) $2.5 \mathrm{~g}$ を得た。クロロホルム溶液は濃縮後アセトン洗 浄によって，アセトン不溶性の結晶（B） $0.9 \mathrm{~g}$ を得た。 （A）溔水より再結晶すると $\mathrm{mp} 181^{\circ} \sim 183^{\circ} \mathrm{C}$ の針状 結晶となり，混融により H A であることを確かめた。 (B) はアセトンより再結晶後 $\mathrm{mp} 170^{\circ} \sim 171^{\circ} \mathrm{C}$ の針状 結晶になり，このものは既報らによより確認した $\mathrm{N}$-ベン ジル馬尿酸アミド（N） との混融で同一物であることを 確認した。さらにN を濃䘏酸で加水分解し, mp $214^{\circ}$ ～ $216^{\circ} \mathrm{C}$ の板状結晶を得た。このものは $\mathrm{N}$-ベンジルグリ シンである。

$\mathrm{HA} 1.1 \mathrm{~g}$ ，水酸化ナトリウム $0.5 \mathrm{~g}$, 液安 $30 \mathrm{cc}$ に 同様にメタル置換を行い塩化ベンジルとの反応の結果 $\mathrm{mp} 170^{\circ} \sim 171^{\circ} \mathrm{C}$ の針状結晶（N） $0.3 \mathrm{~g}$ と末反応 $\mathrm{H} \mathrm{A}$ $0.9 \mathrm{~g}$ を回収した。

$\mathrm{H} \mathrm{N} 3.0 \mathrm{~g}$, 水酸化カリウム $1.5 \mathrm{~g}$ に液安 $50 \mathrm{cc}$ を加 え 5 時間ふりまぜると水酸化カリウム溶解する。塩化 ベンジルとの反応生成物はエーテル抽出液よりジベンジ ルアミン $1.4 \mathrm{~g}$ を，またエーテル不溶物はアルコールよ り再結晶してH N $2.3 \mathrm{~g}$ を回収した。

4. フタリルグリシンエステル，アミド，ニトリルの メタル置換と塩化ベンジルとの反応

P GE $6.0 \mathrm{~g}$ (0.025 mole) および粉末水酸化りチウ ム $0.7 \mathrm{~g}(0.025 \mathrm{~mole})$ に室温で液安 $80 \mathrm{cc}$ を加えてふ。 りまぜると 4 〜 時間で完全に水酸化りチウムは溶解す る。これに塩化ベンジル $3.5 \mathrm{~g}(0.03$ mole $)$ を加えてふ りまぜつゔけると 3 時間でフェノールフタレイン指示薬 の色海無になってベンジル化注終る。さらに一夜放置 後アンモニア蒸発除去し, 生成物を水で洗浄して無機塧 を除き $\mathrm{mp} 155^{\circ} \sim 160^{\circ} \mathrm{C}$ の白色結晶 $2.7 \mathrm{~g}$ を得た。こ のもの㳊回アルコール再結晶をくり返すと, アルコ一 ル難溶部より $\mathrm{mp} 176^{\circ} \sim 178^{\circ} \mathrm{C}, \mathrm{N} ; 8.25 \%$ の針状結 晶 (C) を得, アルコール易溶部よりは $\mathrm{mp} 114^{\circ} \sim 116^{\circ}$ 
$\mathrm{C} ， \mathrm{~N} ; 5.94 \%$ の針状結晶（D）を得るので両者の混合 物と思われる。（D）は文献により合成したベンジルフ タルイミド (VII) と融点および分析值が一致し, 混融の 結果確認した。（C） は濃塩酸で処理すると UI とベンジ ルアミン塩酸塭とに分解することを認め, その窒素分析 も $\mathrm{N}, \mathrm{N}^{\prime}$-ジベンジルフタルアミド(IX)の理論值 $\mathrm{N} ; 8.13$ \% に一致することよりして文献に記載はないが $\mathrm{X}$ であ ると推定される。すなわち X は塩酸処理で脱ベンジル アミンを起して閉環するものと考えられ，二つのベンジ ル基は違った窒素についているものと考える。したがっ て初めの混合物を塩酸で処理し，このばあいに $2.5 \mathrm{~g}$ の UI得た。最初の生成物を洗浄した水溶液は蒸発乾固後 少量のアルコールで抽出し, 塩酸を吹込んでグリシンエ
チルエステル塩酸塩 $\mathrm{mp} 140^{\circ} \sim 143^{\circ} \mathrm{C}$ を確認した。し たがってもとの水溶液中にはグリシンアミドの存在する ことが推定できる。

P G A $1.0 \mathrm{~g}$ ，水酸化カリウム $0.4 \mathrm{~g}$ より同様に反応 を行い, $0.5 \mathrm{~g}$ の叫を得た。

P G N $2.0 \mathrm{~g}$ ，水酸化カリウム $0.7 \mathrm{~g}$ によるメタル置 換を行い， 1 時間で水酸化カリウムは消失した。つぎに 塩化ベンジル $1.5 \mathrm{~g}$ を加えてベンジル化を行い, 反応生 成物としてVII $1.5 \mathrm{~g}$ と少量ではあるが $\mathrm{bp}_{14} 70^{\circ} \mathrm{C}$ の粘 稠液体を得た。このものは沸点および掹酸塩の分解点 $165^{\circ} \mathrm{C}$ がアミノアセトニトリル塩酸䘏のそれと一致す る。

(昭和 29 年 11 月, 東北大学非水研研究発表会講演)

（東京大学理工学研究所, 東京都目黒区）（昭和 32 年３月 26 日受理）

\title{
共 役二重 結 合 系 の研究 (第 12 報) ベンゼンニ置換体の近紫外部吸収スペクトルについて
}

\author{
田 仲 三 朗・長 会 三 郎
}

本報では著者らがこれまで行ってきた分子エネルギー準位図法を用いて，一方に電子供与性の置 換基 $\mathrm{X}$ ，一方に電子索引性の置換基 $\mathrm{Y}$ もつベンゼン二置換体， X- 亿ついて, 紫外部スペ クトルの解析を行った。これらの化合物では $p$-誘導体では近紫外部に強い吸収带が一つしか現わ れないのに， $o, m$-誘導体では二つの吸収帯が現われる。この事実は, 分子エネルギ一準位図の考え をもとにして明瞭に説明され，定性的にる定量的にも十分満足に説明を与えるてとができた。

つぎにてれらの場合を例にして古くからいわれている発色団, 助色団の説に対して, 分子エネル ギー準位図の立場から理論的根拠を与える。

序説

有機化合物の色と化学構造の関係は化学者にとって興 味のある問題である。古くより可視部, 紫外部に強い吸 収帯をもつ化合物にはすべて不飽和二重結合の存在する ことが認められ，発色団説が唱えられてきたが,近年の量 子力学を基にした分子軌道理論の発展によってこの問題 の理論的解明は長足の進歩を遂げた。すなわち MayerSklar1) に始まるベンゼンの ASMO (反対称分子軌道) の計算以来, Craig ら ${ }^{2}$ )により CI（配置間相互作用）

1) M. G. Mayer, A. L. Sklar, J. Chem. Phys. 6, 645 (1938).

2) D. P. Craig, Proc. Roy. Soc. A 200, 474 (1950); R. G. Parr, D. P. Craig, I. G. Ross, J. Chem. Phys. 18, 1561 (1950).
の重要性が認められ, さらに最近には Pariser-Parr' ${ }^{3)}$, Moffitt 5)による半経験的 ASMO+CI の方法が出て, 現在では基本的な不飽和炭化水素のエチレン, ベンゼン 等については紫外部吸収スペクトルの理論はほぼ明確に なりつつある。

ところで，この不飽和炭化水素に置換基が導入された 場合に，スペクトルにどのような影響が現われるかとい う問題は, 古くから多くの研究が行われ, 二トロ基, カ ルボニル基,カルボキシル基等の発色団と,アミノ基, 七 ドロキシル基等の助色団のあることがいわれていた5゙。

3) R. Pariser, R. G. Parr, J. Chem. Phys. 21, 466, 767 (1953).

4) W. Moffitt, Proc. Roy. Soc. A 210, 224 (1951).

5) A. E. Gillam, E. S. Stern, "Electrenic Absorption Spectroscopy" (1954) London. 